AUTHORS:

Sordaini Maria Caligiorne Deborah de Farias Lelis Carlos Eduardo de M Jensen Carina Miranda Soeiro

Juliana Carvalho de Melo

Robson A. Santos

Maria José Campagnole-Santos

Sergio Henrique Sousa Santos

https://doi.org/10.5628/rpcd.17.S3A.78
Bixin and annatto seeds

extract reduces blood

pressure of rats treated with

\section{hypercholesterolemic diet}

KEY-WORDS:

Annatto. Hypercholesterolemia.

Hypertension. Bixa orellana. Bixin.

\title{
ABSTRACT
}

Aim: The present study aimed to evaluate the effect of the treatment with aqueous extract of annatto seed and isolated bixin on the blood pressure of rats treated with a hypercholesterolemic diet. Methods: Extracts of annatto seeds and isolated bixin were administered to 30 male Wistar rats that were divided into six groups $(n=5)$ : standard diet + water, standard diet + annatto, standard diet + bixin, cholesterol diet + water, cholesterol diet + annatto, cholesterol diet + bixin. Body weight and blood pressure were measured. After the treatment period, the animals were sacrificed and blood samples were collected for the measurement of total cholesterol, HDL and triglycerides. The heart, liver and kidney were collected and weighted. Results: The plasma levels of cholesterol were increased in the animals fed a high-cholesterol diet. The blood pressure at the end of the treatment was decreased in the animals treated with bixin. The weight of the organs collected was decreased in the groups treated with the annatto extracts and bixin, as compared to its respective groups. Conclusion: According to the conditions applied in this study, bixin appears to be a potentially therapeutic compound to be used in the treatment of hypertension and hyperlipidemia.

pressão sanguínea de ratos tratados

com dieta rica em carboidratos

RESUMO

Objetivo: 0 presente estudo objetivou-se em avaliar o efeito do tratamento com extrato aquoso de sementes de urucum e bixina na pressão sanguínea de ratos tratados com dieta rica em colesterol. Métodos: Extratos das sementes de urucum e bixina foram administrados à 30 ratos da linhagem Wistar, divididos em seis grupos $(n=5)$ e alimentados por 28 dias com as seguintes dietas: dieta padrão + água, dieta padrão + urucum, dieta padrão + bixina, dieta rica em colesterol + água, dieta rica em colesterol + urucum, dieta rica em colesterol + bixina. 0 peso corporal e pressão sanguínea foram medidos durante o tratamento. Ao final, os animais foram sacrificados e amostras de sangue foram coletadas para mensurações bioquímicas. 0 coração, fígado e rim foram coletados e pesados. Resultados: Os níveis plasmáticos de colesterol aumentaram nos animais alimentados com a dieta rica em colesterol. A pressão sanguínea dos animais tratados com dieta experimental + bixina foi diminuída ao final do tratamento, assim como o peso dos órgãos coletados. Conclusão: De acordo com as condições aplicadas neste estudo, a bixina parece ser um composto com grande potencial terapêutico para ser usado no tratamento de hipertensão e hiperlipidemia.

PALAVRAS CHAVE:

Urucum. Hipercolesterolemia. Hipertensão.

Bixa orellana. Bixina. 


\section{INTRODUCTION}

Cardiovascular diseases (CVD) are the main cause of death in western countries (Cuppari, 2005). In Brazil, CVD are also the leading cause of death, accounting for about $30 \%$ of deaths in all age groups (Santos \& Martinez, 2002).

The global dietary pattern has been changing over the years to diets rich in refined sugars, oils and meat. These changes result in increases in body mass index (BMI), and in the incidence of obesity comorbidities, such as diabetes type 2 and cardiovascular diseases. This global transition, especially to diets rich in lipids, contributed to around 2 billion people turning overweight and obese in the last years (Tilman \& Clark, 2014).

An increase in cholesterol levels in the blood, as well as the pro-oxidant activity of free radicals on low-density lipoproteins (LDL), damages the endothelium, thus causing the development of CVD (Rahman, 2007). Several studies show that the intake of specific substances like guar gum, a galactomannam from Cyamopsis tetragonolo$b a$, identified as potent reducing agents, help to decrease serum levels of cholesterol and LDL (Alvarez, et al., 1994). Studies by Cortela and Pochettino (1997), described that plant specimens such as artichoke (Cynara cardunculus) and rosemary (Rosmarinus officinalis), are also able to lower cholesterol levels. In addition, another class of substances that have often been associated with a reduced risk of coronary events are the carotenoids (Ross et al., 2000)

The carotenoids most commonly found in plant foods are the B-carotene (carrots, Daucus carota), lycopene (tomatoes; Lycopersicum esculentum), several xanthophylls (zeaxanthin lutein and other oxygen corn structures, Zea mays, of mango, Mango indicates; of papaya, Carica papaya and egg yolk) and the bixin (annatto, Bixa orellana) (Fontana \& Mendes, 2000)

Annatto is one of the most used natural dyes, and Brazil is one of the largest producers and exporters of annatto seeds. The application of annatto extracts in foods have suffered severe restrictions in terms of the range of products where it can be added as well as to the allowed concentrations of this extract. One of the allegations is that little is known about the composition of these extracts.

Recent toxicology studies have demonstrated that norbixin, and ultimately the bixin since it is demethylated in vivo, are devoid of significant deleterious effects on hepatic renal and bone marrow cells of mice and rats (Fernandes et. al., 2001; Lima et al., 2002). Although no embryotoxic effect has been demonstrated in rats (Paumgartten, 2002), a considerable degree of interference with the metabolic control of glucose in these rodents was perceived (Fernandes et al., 2001). Reports of the popular use of the plant for the treatment of diabetes mellitus are also reported (Oliveira et al., 2003)

Neves and Caligiorne found that the infusion of annatto seed lowered blood cholesterol levels in rats. Likewise, Pedrosa et al. (Silva et al., 2000) showed similar results, with respect to cholesterol levels. However, these authors did not observe similar results regard- ing the levels of triglycerides. Studies by Lima et al. (2002) using rabbits corroborated the aforementioned findings, where the bixin was able to reduce cholesterol levels.

As the multifactorial mechanisms involved in atherosclerosis have not yet been completely understood, the characterization of drugs that may act in the pathophysiology of the CVD became the target of numerous studies, both in academia, as well as in major pharmaceutical companies. Thus, it is understandable the growing interest in new drugs that can act reducing plasma cholesterol levels with antioxidant and vasodilator activity (Cascieri, 2002).

In this sense, the present study aimed to evaluate the effect of the treatment with aqueous extract of annatto seed and isolated bixin on the blood pressure of rats treated with a hypercholesterolemic diet.

\section{MATERIALS AND METHODS}

PREPARATION OF THE AQUEOUS EXTRACT OF ANNATTO SEEDS

The extract of annatto seeds was prepared with 35 annatto seeds, which were embedded in $125 \mathrm{ml}$ of potable water following a resting period of approximately 12 hours. The preparation was then provided ad libitum to the experimental group.

EXTRACT PREPARATION OF ANNATTO SEEDS - BIXIN

The bixin was extracted from annatto seeds according to the methodology described by Costa and Chaves (2005) with modifications. The extractions were performed with $\mathrm{NaOH}$ solution at $5 \%$, and precipitated with $\mathrm{H} 2 \mathrm{SO} 420 \% \mathrm{~V} / \mathrm{V}$, obtaining an average yield of $3.5 \%$. The bixin was then given to the animals in the proportion of $0.1 \mathrm{~g} / 100 \mathrm{~g}$ of diet.

ANIMALS AND DIETS

The experiment was conducted with 30 male Wistar rats, divided into six groups $(n=5)$ and fed the following diets for 28 days: standard diet + water (ST), standard diet + annatto (ST+A), standard diet + bixin (ST+B), cholesterol diet + water $(\mathrm{Hcol})$, cholesterol diet + annatto $(\mathrm{Hcol}+\mathrm{A})$, cholesterol diet + bixin $(\mathrm{Hcol}+\mathrm{B})$. During the treatment, the animals were kept in individual cages at room temperature $\left(23 \pm 1^{\circ} \mathrm{C}\right)$ under a 12 hour light and dark cycles (6:00 am to 6:00 pm), and weighed at the beginning, with 10,20 and 28 days. All diets were purchased from Rhoster ${ }^{\oplus}$, LTDA (São Paulo, Brazil), with the composition details as follows: standard diet (AIN-93M): cornstarch $(46.57 \mathrm{~g})$, casein $(1.0 \mathrm{~g})$, dextrinized cornstarch $(15.5 \mathrm{~g})$, sucrose $(10.0 \mathrm{~g})$, soybean oil $(4.0 \mathrm{~g})$, fiber (5.0), mineral mix (ain-93g-mx) (3.5g), vitamin mix (ain-93-vx) (1.0g), l-cystine (0.18g), choline bitartrate $(0.25 \mathrm{~g})$ and tert-butylhydroquinone $(0.0008 \mathrm{~g}) .1 \%$ cholesterol diet (AIN-93M): cornstarch $(46.57 \mathrm{~g})$, casein $(1.0 \mathrm{~g})$, dextrinized cornstarch $(15.5 \mathrm{~g})$, sucrose $(10.0 \mathrm{~g})$, soybean oil (4.0g), fiber (5.0), mineral mix (ain-93g-mx) (3.5g), vitamin mix (ain-93-vx) (1.0g), l-cystine $(0.18 \mathrm{~g})$, choline bitartrate $(0.25 \mathrm{~g})$, tert-butylhydroquinone $(0.0008 \mathrm{~g})$ and cholesterol $(1.0 \mathrm{~g})$. 
This study was approved by the Ethics Committee of Experimentation and Animal Welfare of Unimontes, Montes Claros, Brazil (process number 121/2016) and was conducted in accordance with the guidelines described in the Committee's Guiding Principles Manual.

\section{LIPID PROFILE}

The plasma levels of HDL-cholesterol and triglycerides were determined from the blood collected at the end of the treatment after the sacrifice.

Total cholesterol levels were measured according to the cholesterol oxidase method (Allain et al. 1974), using a commercial kit from the company Doles, Brazil. The method consists in hydrolysis of cholesterol esters by cholesterol esterase, which produces free cholesterol, and oxygen, and in turn producing hydrogen peroxide, which, by the action of the peroxidase in the presence of phenol, and 4-aminoantipyrine, produces a reddish pink compound with a maximum absorption at $505 \mathrm{~nm}$. The total cholesterol levels determined on the liver tissue and the triglyceride and HDL in the plasma of the animals were determined by a spectrophotometer. The concentration of the total cholesterol was determined from a standard concentration of $200 \mathrm{mg} / \mathrm{dL}$.

MEASUREMENT OF CARDIOVASCULAR PARAMETERS

Blood pressure measurements were made using the tail plethysmograph. The pressure is measured after the rats tail being cuff on the root in a pressure higher than the systolic level, being gradually reduced. When the volume of the blood in the tail increases, it is thus detected by a plethysmograph (Byrom \& Wilson, 1938). The systolic pressure was measured in the animals before and at the end of the treatment ( 28 days).

\section{TISSUE COLLECTION}

After the sacrifice, the heart, liver and kidney were collected and weighted for posterior analysis.

STATISTICAL ANALYSIS

For the analysis of the differences between the averages of two groups, we used the Student $t$ test for unpaired observations. To compare more than two groups of animals, the analysis of variance (ANOVA) was used, followed by Bonferroni post-hoc test. Statistical analyzes were performed in Graphpad Prism (version 4.0). The level of significance was set at $p<0.05$. All values were expressed as mean \pm standard error of the mean (SEM)

\section{RESULTS}

The results showed no statistical significant differences regarding the body weight of the animals at the end of the treatment (SEE FIGURE 1). Interestingly, although the body weight did not present significant variations among groups, the levels of total cholesterol on the liver indicates a state of hypercholesterolemia, which was induced by the high-cholesterol diet given to the animals $(p<.0001)$ (SEE FIGURE 2A)

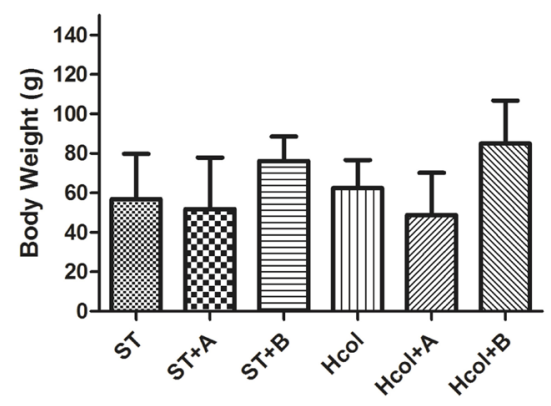

FIGURE 1. Body weight (g) of rats fed a standard diet (ST) and high-cholesterol diet (Hcol) and treated with aqueous extract of annatto seeds and bixin $(\mathrm{ST}+\mathrm{A}, \mathrm{ST}+\mathrm{B}, \mathrm{Hcol}+\mathrm{A}$ and $\mathrm{Hcol}+\mathrm{B})$. ${ }^{*} \mathrm{p}<.05 ;{ }^{* *} \mathrm{p}<.01 ;{ }^{* * *} \mathrm{p}<.001$ (t-tests, one-way ANOVA and Bonferroni post-test).

The plasma levels of triglycerides were not statistically different comparing the animals fed a standard diet with the animals fed a high-cholesterol diet and its respective treatment groups (FIGURE 2B). Similarly, the plasma levels of HDL (mg/L) obtained at the end of the experiment showed no statistically significant changes in blood HDL mean values among the treatment groups. Although we did not observe statistically significant differences, a reduction in blood HDL levels in the group fed Hcol and ST compared with its respective treatment groups was observed. Likewise, it could be verified that the group of animals fed standard and bixin and cholesterol and bixin, the HDL mean values remained similar to the respective control groups (FIGURE 2C).
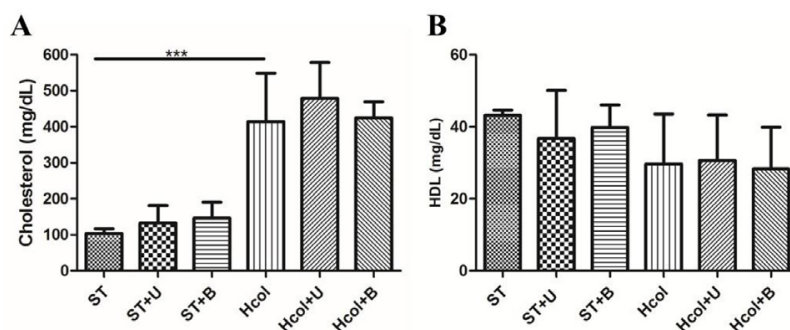

IGURE 2. Lipid profile of rats fed a standard diet (ST) and high-cholesterol diet (Hcol)

nd treated with aqueous extract of annatto seeds and bixin $(S T+A, S T+B, H c o l+A$ and $\mathrm{Hcol}+B)$

(A) Levels of total cholesterol (mg/dL) (B) Plasma levels of HDL $(\mathrm{mg} / \mathrm{mL}$ ) (C) Plasma levels of triglycerides $\mathrm{mg} / \mathrm{mL}$ ). ${ }^{*} \mathrm{p}<.05 ;{ }^{* \star} \mathrm{p}<.01 ;{ }^{* \star \star} \mathrm{p}<.001$ (one-way ANOVA and Bonferroni post-test). 
The blood pressure measurements performed at the beginning of the treatment showed no significant statistical difference among groups (FIGURE 3A). On the other hand, the blood pressure measurements taken at the end of the treatment period showed a significant decrease in the blood pressure levels of the animals fed a high-cholesterol diet along with bixin as compared to the other groups of animals ( $p=.0038$ ) (FIGURE 3B).

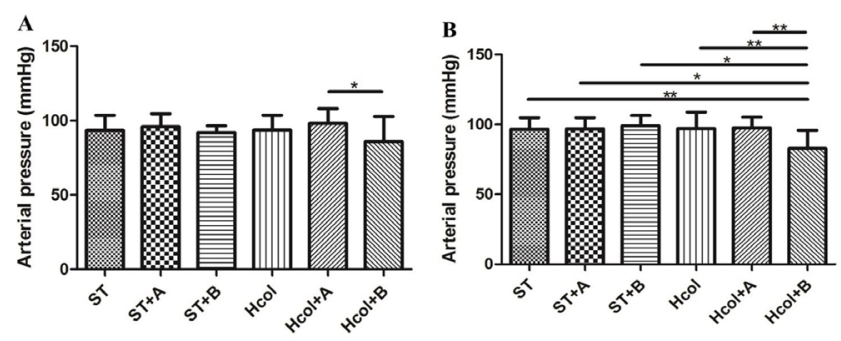

FIGURE 3. Systolic pressure of rats fed a standard diet (ST) and high-cholesterol diet (Hcol) and treated with aqueous extract of annatto seeds and bixin (ST+A, ST+B, Hcol+A and Hcol+B). (A) Arterial pressure at the beginning of the treatment (day zero) $(\mathrm{mmHg})$. (B) Arterial pressure at the end of the treatment $\left(28\right.$ days) $(\mathrm{mmHg}) .{ }^{*} p<.05 ;{ }^{* *} p<.01 ;{ }^{* * *} p<.001$ (one-way ANOVA and Bonferroni post-test).

Additionally, the weight of the liver, heart and kidney were measured and the weight was corrected by the body weight of the animals. It was observed that the animals fed a standard diet in addition to annatto seeds extract and bixin and the animals fed a high-cholesterol diet in addition to annatto seeds extract and bixin had a reduction in the weight of the liver $(p<.0001)$, heart $(p<.0001)$ and kidney $(p<.0001)$ as compared to its respective control groups (ST and Hcol) (FIGURES 4A, 4B, AND 4C).
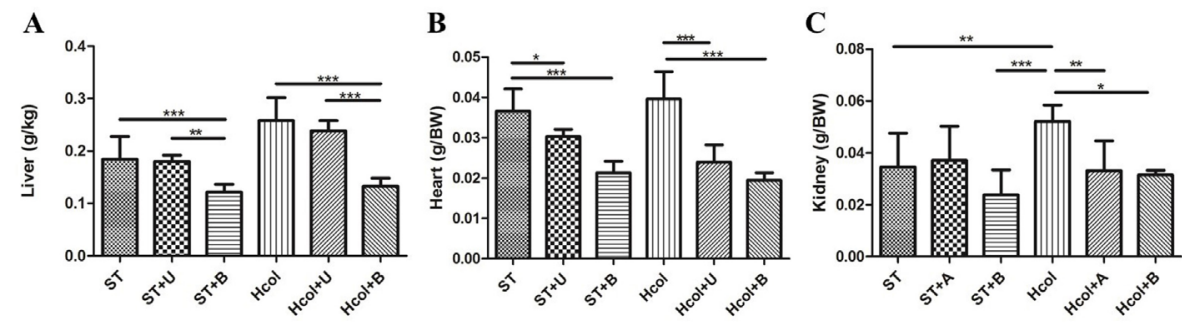

FIGURE 4. Effects on liver, heart and kidney weight of rats fed a standard diet (ST) and high-cholesterol diet (Hcol) and treated with aqueous extract of annatto seeds and bixin (ST+A, ST+B, Hcol+A and Hcol+B). (A) Liver weight (g/BW) (B) Heart weight $(\mathrm{g} / \mathrm{BW})$. (C) Kidney weight $(\mathrm{g} / \mathrm{BW}) .{ }^{*} \mathrm{p}<.05 ;{ }^{* *} \mathrm{p}<.01 ;{ }^{* * *} \mathrm{p}<.001$ (one-way ANOVA and Bonferron post-test).
Animal models have been used to investigate the relationship between disorders in cholesterol metabolism and blood pressure (Matos et al. 2005). The present study showed that the dietary model used was able to promote hipercholesterolemia and that the treatment with extracts of annatto seeds and bixin was able to decrease the blood pressure of rats.

It was expected that the bixin would be able to decrease the cholesterol levels of animals fed high-cholesterol diet along with bixin extract. However, no significant differences were observed in the groups for the levels of total cholesterol and triglycerides. In addition, the bixin, in these conditions of experimentation was not able to increase the levels of HDL. All these findings that regards the lipid profile of the animals, allow us to conclude that in the conditions tested in this study did not affect the animal's metabolism.

Our findings do not corroborate with a study published by de Paula and cols. where rats fed a high-cholesterol diet along with aqueous extract of annatto seeds had their levels of total cholesterol and LDL decreased and increase in the levels of HDL (Paula et al., 2009). This difference may be due to the experimental conditions, such as concentrations of the compounds and diet composition that might be different between the two studies.

Another interesting finding of our study, was the decrease in the weight of the liver, kidney and heart of animals treated with aqueous extract of annatto and bixin as compared to its respective control groups. We suggest that the bixin, and in some groups the aqueous extract of annatto seeds, were able to reduce the lipid accumulation in these organs, thus decreasing the weight. Specifically in the liver, other studies have shown that the cytochrome p450monooxygenase system is activated by the annatto, thus increasing the oxidative activity, which may account for the decrease in the lipid accumulation in this organ (Jewel \& O'Brien, 1999; Oliveira et al., 2003).

In the present study, no reduction in systolic pressure was observed in animals fed a standard diet after 28 days of treatment. This indicates that the standard diet did not influence the blood pressure of the animals. These data are consistent with the findings of (Matos et al., 2005) who carried out a tail pressure measurement with plethysmography in rats that received different diets. However, our data showed a significant reduction in the blood pressure levels in animals that received hypercholesterolemic diet in addition of bixin. As the bixin was not able to significantly decrease the cholesterol levels, we may suggest that this compound participated in the decrease of the blood pressure by other pathways that need further analysis to be identified and elucidated.

The treatment led to a reduction on the animal's blood pressure to levels below the value of the control period, which suggests its effectiveness in reducing this parameter. Thus, the bixin may be considered a compound with potentially therapeutic activity to be used in the treatment of hypertension, which is a frequently present comorbidity found in obese patients. 
It can be concluded that in the experimental conditions described in this study, the bixin was able to ameliorate the increase in the blood pressure caused by a high-cholesterol based diet and to decrease the weight of the liver, heart and kidney of rats. However, further investigations regarding the pathways by which the bixin may act to decrease the blood pressure are highly encouraged. Additionally, studies regarding the histology of the cardiac, hepatic and renal tissues may help to understand the role of bixin in these systems.

\section{ACKNOWLEDGEMENTS}

Regina Celia, for the care of the experimental animals. Ramon Silva, for the technical support. Prof. Dr Luis Fernado Soares for the the scientific support.

\section{FINANCING SOURCE}

This work was also partially supported by grants from Coordenadoria de Aperfeiçoamento do Pessoal de Nível Superior (CAPES), Conselho Nacional de Desenvolvimento Científico e Tecnológico (CNPq), Fundação de Amparo à Pesquisa de Minas Gerais (FAPEMIG), Centro Universitário Newton Paiva and the FUNADESP.
Allain, C. C., Poon, L. S., Chan, C. S., Richmond, W., \& Fu, P. C. (1974). Enzymatic determination of total serum cholesterol. Clinical Chemistry, 20(4), 470-475.

Alvarez-Leite, J. I., Andrieux, C. Ferezou, J. Riottot, M., \& Vieira, E. C. (1994). Heat or gamma irradiation sterilization affects the hypocholesterolemic effect of guar gum in axenic and heteroxenic rats. Brazilian Journal of Medcal and Biological Research, 27(3), 677-689.

Byrom, F. B., \& Wilson, C. (1938). A plethysmographic method for measuring systolic blood pressure in the tact rat. The Journol of Physiology 03(3), 301-304.

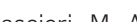
2002). The potential for novel antiinflammatory therapies for coronary artery disease. Nature Reviews Drug Discovery, 1, 122-130. doi:10.1038/nrd72

Cortella, A. R., \& Pochettino, M. L. (1997). Análisis y evaluación de los 'tés' comercializados para el tratamiento del colesterol. La Alimentacion Latinoamericana, 31, 49-57.

Costa, C. L. S. Da, \& Chaves, M. H. (2005). Extração de pigmentos das sementes de bixa orellana L.: Uma alternativa para disciplinas experimentais de química orgânica. Química Nova, 28, 149-152. doi:10.1590/ S0100-40422005000100026

Cuppari, L. (2005). Guia de nutrição: Nutrição clínica no adulto (3a Ed.). Manole.

de-Oliveira, A. C. A.X. Silva, I. B, Manhaes-Rocha, D. . monooxygenases by annatto and bixin in female rats. Brazilian Journal of Medical and Biological Research. 36, 113-118.

Fernandes, M. L., Saad, M. J., \& Velloso, L. A. (2001) Effects of age on elements of insulin-signaling pathway in central nervous system of rats. Endocrine, 16 227-234. doi:10.1385/ENDO:16:3:227.

Fontana, J. D., Mendes, S. V., Persike, D. S., Peracetta L. F., \& Passos, M. (2000). Carotenóides: Cores atraentes e ação biológica. Biotecnologia, Ciência e Desenvolvimento, 2 (13), 40-45.

Jewell, C., \& O'Brien, N. M. (1999). Effect of dietary supplementation with carotenoids on xenobiotic metabolizing enzymes in the liver, lung, kidney and small intestine of the rat. British Journal of Nutrition, 81 (3), 235-242.

Lima, L. R. P., Oliveira, T. T., Nagem, T. J., Pinto, A. S. Stringheta P. C. Tinoco, A. L. A. \& Silva, J. F. (2001) Stringheta, P. C. Thoco, A. L. A. \& Siva, J. F. (2001).

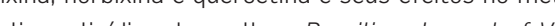
bolismo lipidico de coelhos. Brazilian Journal of Veterinary Research and Animal Science, 38, 196-200. doi:10.1590/S1413-95962001000400010.
Matos, S. L., Paula, H., Pedrosa, M. P., Santos, R. C.. Oliveira, E. L., Júnior, D. A. C.., \& Silva, M. E. (2005). Dietary models for inducing hypercholesterotemia in rats. Brazilian Archives of Biology and Technology, 48(2) 203-209. doi:10.1590/S1516-89132005000200006 Paula, H., Pedrosa, M. P., Rossoni, J. V., Haraguchi, F. K., Santos, R. C., \& Silva, M. E. (2009). Effect of an aqueous extract of annatto (bixa orellana) seeds on lipid profile and biochemical markers of renal and hepatic function in hipercholesterolemic rats. Brazilion Archives of Biology and Techology, 52(0), 1373-1378. doi:10.1590/S1516-89132009000600008

Paumgartten, F. J., de-Carvalho, R. R., Araújo, I. B. Pinto, F. M., Borges, O. O., Souza, C. A., \& Kuriyama, S. N. (2002). Evaluation of the developmental toxicity of annatto in the rat. Food and Chemical Toxicology 40(11), 1595-1601.

Rahman, K. (2007). Studies on free radicals, antioxidants, and co-factors. Journal of Clinical Interventions in Aging, 2, 219-36.

Ross, A., Caballero, C., Shike, B., Shils, M., \& Cousins M. R. (2003). Nutrição moderna na saúde e na doença (10å Ed.). São Paulo: Manole.

Santos Filho, R. D., \& Martinez, T. L. R. (2002). Fatores de risco para doença cardiovascular: Velhos e novos fatores de risco, velhos problemas! Arquivos Brasileiros de Endocrinologia \& Metabologia, 46, 212214. doi:10.1590/\$0004-27302002000300002.

Silva, M. E., Paula, H., Ansaloni, J. A., Chaves, C. R. C., \& Pedrosa, M. L. (2000). Efeito do chá de urucum (bixa orellana) sobre parâmetros do metabolismo em lipídios em ratos. In Simpósio Sul-Brasileiro de Alimentação e Nutrição: História, Ciência e Arte (pp. 231-235).

Tilman, D., \& Clark, M. (2014). Global diets link environmental sustainability and human health. Nature, 515. 518-522. doi:10.1038/nature13959 